\title{
EAST and SOUTH AFRICA: Spillover Effect of Conflicts
}

\author{
Lucie KONEČNÁ
}

\begin{abstract}
The article aims to present four conflicts in East and South Africa that spilled over into neighboring states. The article covers a limited period of time from the end of the Cold War to the present and focuses on the area of East and South Africa. All these conflicts are briefly introduced and the author concentrates mainly on the description of the spillover effect (it includes, for example, the phase of the conflict in which the conflict spilled over to a neighboring state, timing, interconnection or cooperation of armed groups). The most important goal of the article is to analyze conditions based on conflict theories and spillover effect theories that led to the spillover into these states and compare them with other neighboring states, where the conflicts did not occur.
\end{abstract}

Keywords: Conflict; Cooperation; Neighboring state; Security; Spillover effect; War.

\section{Introduction}

After the end of the Cold War, there were several positive but also some negative trends in conflict studies. Positive is that there is a reduction in the number of interstate wars and the number of deadly wounded soldiers on the battlefield has been decreasing as well. On the other hand, the number

Lucie KONEČNÁ M.A.

Ph.D. candidate

Faculty of Social Science

Masaryk University

E-mail: 397816@mail.muni.cz

Conflict Studies Quarterly

Issue 30 , January 2020, pp. 31-54

DOI:10.24193/csq.30.2

Published First Online: 05/01/2020 of national wars is higher and, moreover, these conflicts negatively affect the civilian population that has to be resettled. At the same time, civilian losses are increasing, which are several times higher than in the wars before the year 1990. Africa has the highest conflict potential, the end of the Cold War has not brought a peaceful period there, while many conflicts, which were suppressed due to bipolar rivalry and the interest of the superpowers, broke out with even greater intensity. Not only the end 
of the Cold War but also other factors such as natural conditions and inefficient economic development, ethnic hatred and tribalism (largely influenced by colonialism and decolonization), high level of poverty or instability of state institutions are important factors affecting Africa's conflict environment. This is confirmed by statistics that show that over $40 \%$ of all African countries have been affected by at least one civil war over the past 40 years (Elbadawi \& Sambanis, 2009, p. 3).

One of the phenomena that occur in conflicts in Africa is its spillover effect. In a few cases, we may have seen that a conflict that began in a domestic state has spilled over into neighboring states. I do not mean the internationalization of a conflict that involves governments of two states fighting against each other. In these cases, the national war caused destabilization and chaos in a neighboring state, and these negative effects caused the outbreak of a new civil war in that state. In these new conflicts, in the vast majority of cases, militias from neighboring states (not state ones), abuse the unstable situations in the neighboring state to expand their activity. In some cases they are directly involved, in other cases, they only support rebel groups in neighboring countries. The key to this phenomenon of conflict spillover is the continuity of time and the involvement of actors from the neighboring state. However, why is in some cases, the neighboring state destabilized and conflict spilled over, and in others not? I will describe this on the example of conflicts from East and South Africa.

East Africa is a region rich in human capital, but other characteristics include harsh climatic conditions (frequent droughts), increasing environmental degradation, poverty, political instability or high conflict potential. Somalia is part of this area. It is a very unstable state and a civil war has been going on there since 1991. The war spilled over into neighboring Ethiopia. Another conflict that spilled over to a neighboring state is the civil war in Ethiopia that spilled over to Djibouti. In contrast, South Africa is a more stable region than the Eastern one. However, even there, the security situation is not good, there is a very high crime rate, a high influx of refugees and uneven population geography. All these factors increase the conflict potential, and therefore we can find conflicts that have spilled over also in this region. Specifically, it is a civil war in Angola that spilled over to Namibia and the conflict in Cabinda (Angola), which spilled over to the Republic of Congo. In this article, I will describe these four case studies and focus on spillover analysis.

\section{Theoretical Framework}

A number of world authors have been concerned with the definition and classification of conflicts over the years. In the most general sense, conflict can be expressed as a state of competition between two or more actors who have incompatible interests. However, not every dispute or tense situation can be considered as a conflict. The conflict has certain characteristics. According to Holsti (1991), the conflict must have these specific 
characteristics: actors (at least one of them is state actor), a definable area of conflict interests, present tensions, and conflicting actions. Very often used criteria are those from Smolík and Šmíd (2010). They divide them into the qualitative and quantitative categories. On the basis of these criteria, national conflicts can be considered as a war when at least one of the armed forces is subordinate to governmental power, at the same time showing a managed organization, a determined strategy, and continuity of operations. The quantitative criterion of 1,000 dead per year determines the most intense kind of conflict - war (Smolík \& Šmíd, 2010, pp. 18-25). The civil war is a kind of conflict that, like conflict, has been described by many authors. In my opinion, the aptest criteria of the civil war were determined by Fortna (2008). The civil war has killed over 1,000 people over its lifetime, taking place within the internationally recognized borders of a sovereign state, threatening the sovereignty of that state, one of the struggling parties being state troops, rebels are organized and capable of causing losses to the state (Fortna, 2008, pp. 2-5). These criteria clearly determine what civil war is.

\section{The Spillover Effect}

The Spillover Effect is a relatively new concept in security studies that have been taken from economics. This concept is very often mentioned but without some theoretical anchoring. Kofi Annan's statement is well known in this context. He claimed that wars in neighboring states will not leave the surrounding states intact (Whitaker, 2003, p. 1). One of the most famous conflict scientists, Paul Collier, works with the spillover effect too. According to Collier (2007), civil war flows from the countries concerned not only to neighboring countries but also to more distant states through terrorism, drug trafficking and the spread of epidemics (Collier, 2007, p. 147). Thus, there is a spillover of threats from states in conflict. Collier, however, did not pay close attention to this phenomenon and focused primarily on the trap of conflict and the causes of civil wars. Another well-known author who mentions this phenomenon in his work is Stewart Patrick. Patrick (2006) states that weak and failing states are very often the place where threats such as terrorism, proliferation, and crime are spilling from. Thus, the author does not associate the concept of spillover with the spillover of conflicts and wars, but rather with the spillover of threats that may cause instability in neighboring countries and undermine security. Patrick argues that the relationship between state weakness and spillover is not linear. It always depends on the type of threats, and on religious, geographical, and cultural factors (Patrick, 2006, pp. 7-17). A similar study was published by the African Development Bank, which describes the impact on the neighboring state and the spillover of threats from conflict-affected states. They divide these threats into social and economic. Economic threats and impacts include e.g. disruption of infrastructure or decline in economic performance. Social threats include, for example, the influx of refugees or the spread of diseases and HIV / AIDS (African Development Bank, 2008, pp. 11-19). 
There are several authors who dealt with the spillover effect in more detail. Among the most important work is the work of Bosker and de Ree, who conducted research on spillovers in 2009. Based on historical events and mathematical calculations, they tried to determine whether conflicts spilled over and how probable it is. As a result of their study, conflict spillover is a phenomenon that can only be confirmed in Africa. It can also be argued that if a given African country is adjacent to at least one conflict country, the risk of conflict in that country is about 4\% higher (Bosker \& de Ree, 2009). Silve and Verdier (2018) studied the theory of regional security complexes. At the same time, however, they also focused on the spillover threats that spread within the complex when a civil war is taking place in one of the states. They determined the so-called main elements of instability, which undermine security within the complex and can lead to the outbreak of war in another state. These elements of instability include the proliferation of small arms, the high influx of refugees and ethnic cross-border ties. They also described the negative impact of the size and porosity of the border and the instability of state institutions. Terrill (2008) described conflict spillovers over Iraq. According to him, there are four spillover factors, which can then lead to conflict. The first is the influx of refugees and displaced persons, the second is cross-border terrorism, the third is an international crime and organized crime, and the fourth is the intensification of separatism (Terrill, 2008).

According to available research, threats such as enormous migration, terrorism, and arms trafficking spillover when a neighboring African state is hit by the conflict. At the same time, these threats weaken the economic performance of neighboring states. All these factors weaken neighboring states, and in some cases, the conflict itself actually spillover, especially in Africa. In order to discuss conflict spillovers and not just the outbreak of a new conflict in a neighboring state, certain conditions must be met. The vast majority of spillover authors define a certain continuity of time. This is defined by the period during which the conflict in the neighboring state takes place, and most of them add to this period five another years after the conflict itself ends. This period of time, therefore, clearly determines the continuity of the spillover effect. I also work with this definition of time continuity in my research. At the same time, I add the second and third conditions, which, in my opinion, are crucial. Otherwise, it cannot be clearly demonstrated that this is a spillover of the conflict and not a mere outbreak of a new conflict in a state which has been weakened, for example, by unfavorable regional developments. The second condition is the involvement of some of the same actors. This is mostly a certain anti-state militia that can physically engage in the fighting itself in a neighboring state, but indirect involvement is also sufficient, it usually involves financial technical or logistical support. The second key factor is, therefore, the involvement of some actors from the conflict that spilled over to a neighboring state. The third condition for a clear definition of the spillover effect is cooperation, a certain degree of cooperation between the actor from the original conflict and one of the actors involved in the 
conflict in the neighboring state where the conflict spilled over. These three conditions for defining the spillover effect have been determined on the basis of the analysis of the above-mentioned literature on spillover effect, as well as on the basis of the analysis of several case studies of a spillover effect from East and South Africa.

\section{Methodology}

The first goal of this work is to describe the spillover effect of conflicts on cases from East and South Africa. This describes how the spillover effect works and focuses on the time continuity of conflict's spillover and the involvement of cross-border actors. As a result, the spillover effect of conflicts in Africa can be described. Descriptive-analytical techniques and comparisons are used for this purpose. The cases were selected on the basis of similarity, namely Mill's method of matching, the two examined phenomena have one factor in common (Kouba, 2008, p. 116). In this case, the dependent variable (spillover of conflict) is common for all cases. All cases are geographically close and meet the necessary conditions that differentiate the spillover effect from the outbreak of a new conflict. In includes time continuity, the involvement of cross-border actors and cooperation.

The second goal of my thesis is to determine which factors characterizing neighboring states were present at the moment when the conflict spilled over, and how these factors differed from the states without spillover effect. Based on theories about spillover effect, causes of conflicts and regional security complexes, I have identified factors characterizing a neighboring state that may affect the spillover and unleashing of a conflict in a neighboring state. I have divided these factors into four categories: social, politicalsecurity, economic and geographical. I have worked with several dozen authors to cover the widest possible range of factors. Among the theorists mentioned in the theoretical part about spillover, it includes Patrick (2006), Silve and Verdier (2018), Terrill (2008), Millett (2002), African Development Bank, Carmignani and Kler (2013) and Whikater (2003). At the same time, I have also worked with publications by other well-known scientists, like Galula (1964), which describes the conditions in states where it is easier for rebels to prepare a successful uprising. Galula defines a number of geographical factors. From these mentioned factors I have chosen five, which are easily mathematically expressed and therefore can be incorporated into my analysis. Galula also describes the economy and level of development. It is the reason why I work with the value of GDP (Galula, 1964). In addition to GDP, I have added two factors related to the occurrence of natural resources, which Collier describes in his work, saying that if these factors are met, the chances of a conflict eruption are much higher (Collier and Hoeffler 1999). Other authors, included in my work, are Ncube and Jones, who characterize the causes of conflicts in Africa and define the factors that influence the outbreak of conflicts. Based on the theories of these authors, I, therefore, characterized other factors that increase the chances of conflict's spillover and its outbreak in a neighboring state. Among the 
above-mentioned factors, I added a high incidence of terrorist attacks and a human development index. Other factors, with the exception of weapons proliferation, have already been included. Proliferation cannot be included because there is no accurate and relevant data on Africa for this phenomenon. At the same time, other factors not mentioned by these authors have been included. Many other authors and institutions consider these factors as a weakening element of the state, increasing the likelihood of conflict. This is, for example, a high influx of refugees, described by Enghoff, Hansen, Umar, Gildestad, Owen and Obara (2010, pp. 67-76), Gomez, Christensen, Araya, and Harild (2010, pp. 7-20) or FFP, which measures the Fragile State Index. In addition, Carmignani and Kler (2013) or Whitaker (2003), which I have already mentioned, mention the influx of refugees as a risk factor. Some factors are also included on the basis of the Fragile State Index (FFP) theories, namely humanitarian disaster, high crime rates and the presence of armed active militias. The overall distribution of factors can be seen here:

\section{SOCIAL FACTORS:}

a) High occurrence of the same ethnicity in neighboring states

b) High occurrence of the same religion in neighboring states

c) Humanitarian disaster (e.g. famine)

d) Common war history

e) Low human development index (life expectancy, literacy + income)

f) A high influx of refugees

\section{POLITICAL-SECURITY FACTORS:}
a) The different political ideology of the neighboring state
b) High level of terrorism
c) The political instability of a neighboring country
d) The high crime rate of a neighboring country
e) Existence of armed active militias
f) Small army

\section{ECONOMIC FACTORS:}
a) Presence of important natural resources in the border area
b) Dependence on exports of one natural resource
c) Low GDP

\section{GEOGRAPHIC FACTORS:}
a) Porous and long borders
b) Size of neighboring state (large state)
c) The population of the neighboring state (populated)
d) Uneven population demography
e) Uneven ethnic demography 
For the purposes of this research, I use qualitative comparative analysis with sharp sets, which uses Boolean logic to determine the necessary and sufficient conditions for the occurrence of a given phenomenon. ${ }^{1}$ The characteristics of the neighboring states are divided into four categories based on social, political, economic and geographical factors. Subsequently, truth tables are created for individual cases. Columns consist of individual variables (factors and result), rows represent all hypothetically possible combinations of factors (Beneš \& Drulák, 2016, p. 86). These tables are used for all factors involved in all neighboring states. Data on social, political-security, economic and geographical factors are converted, calibrated to 0 and 1 ( 1 indicating the occurrence and 0 the opposite). Thus, dichotomous data encoding occurs (Ragin, 2008, p. 131). Then I compare what factors (within the QCA condition) were present in the conflict that spilled over and whether these factors were present in situations where the spillover effect did not occur. The cases of spillover effects will be compared with each other - whether there are factors that are the same for each case. For some of these factors, values can simply be converted to 0 or 1 , depending on whether or not the phenomenon occurs in the neighboring state. For others, a threshold is created based on the African or regional average.

\section{Spillover Effect of Conflicts in East Africa}

After the end of the Cold War, two conflicts spilled over into neighboring states in East Africa. The first is the civil war in Somalia, which has been going on from 1991 to the present. After the overthrow of the Barre regime in 1991, a power vacuum emerged in a country that various armed factions and militias tried to fill. The most famous militias were those of Ali Mahdi Muhammad and Muhammad Farah Aidid (Pham, 2013, pp. 135-137). Individual clans and militias divided the territory of the country and fought each other in almost all parts of the state. There were total anarchy, chaos and mass movements in the country. After the end of the foreign intervention in 1995, clashes between individual militias continued, but not to the same intensity as in previous years. Until 2000, fighting took place only in certain areas. In 2001, the Union of Islamic Courts (UIC) was created (Williams, 2009, p. 515). UIC also formed armed factions, which during 2006 conquered the most important strategic sites, including the capital Mogadishu. The UIC subsequently disintegrated into several fractions. The most radical faction that has waged war against the government since 2007 until now is the Islamic terrorist group, Al-Shabaab. Another, previously active, terrorist organization, which has already disappeared, was Hizbul Islam. This conflict, spilled over into one of the federal states of Ethiopia, into Ogaden.

1 Boolean logic deals with logical operations on a set of values $\{0,1\}$. I also use this set in my research (Caramani, 2009, p. 25). 
The second conflict that spilled over was the civil war in Ethiopia, which took place in 1974-1991. Spillover to neighboring Djibouti occurred after the end of the Cold War, so I work with this case as well. In 1974, part of the army formed the Coordinated Council of the Armed Forces of the Police and Territorial Army, which they called the Derg. Derg carried out a coup d'état and overthrew the emperor. There were several opposition groups in the country trying to weaken the power of the Derg and fight against it. One of the most famous groups was the WSLA (Western Somali Liberation Front), an irredentist movement that operated in the Ogaden region. In the 1980s, a series of uprisings took place mainly in the Eritrean area (which at that time belonged to Ethiopia) and in the Tigrai area. At that time, the EPLF (Eritrean People's Liberation Front), whose goal was the secession of Eritrean territory, was particularly active. TPLF (Tigray's People Liberation Front), which had similar secessionist goals, cooperated with EPLF. The government has prepared several attacks against the EPLF and TPLF. The aim of these attacks was the total destruction of these organizations. Operations such as Shiraro, Lash and Adwa were launched, but these attacks were not successful. TPLF together with several other groups formed at the turn of 1988/1989 organization Ethiopian People's Revolutionary Democratic Front (EPRDF), which, with the support of local residents and the United States of America, managed to depose Derg in 1991. During 1990, Mengistu's army was pushed into the capital, then Mengistu fled the country, and the army surrendered to the EPRDF (Vestal, 1999, p. 75). The following sections describe the spillover of these two conflicts to neighboring states.

\section{Spillover of Conflict from Somalia to Ethiopia}

The conflict in Ogaden began in 1994, three years after the outbreak of the civil war in Somalia. One of the fighting parties of the conflict is ONLF (Ogaden National Liberation Front), the other is the military-led party EPRDF. ONLF was officially established in 1984, but until 1994 it was a non-violent organization that tried to promote its interests mainly through political channels. ONLF took part in the 1992 elections, the new elections following the overthrow of the previous communist regime, and ONLF became the main party in the regional parliament after these elections. The main aim of ONLF is the right to self-determination of Somalis in Somali federal state Ogaden, the secession of the area, or at least gaining autonomous status. This, of course, is not compatible with the goals of the central government (Vaughan, 2011). The situation became more pronounced during and immediately after the first elections in 1992 . Several members of ONLF disappeared, others were found dead under unclear circumstances. The situation in the region began to be alarming, the population rebelled and therefore the central government led by the EPRDF decided in 1994 to abolish the regional parliament in Somalia. From this year ONLF declared a violent campaign against the central government (Dagne, 2010). Because the organization did not have enough means and capacities, it resorted to the strategy of hit and run during the 90s. 
During the 1990s, the organization carried out a series of attacks on government and military targets. Most of them were bombings. Between 2003 and 2004, the government took an offensive to destroy ONLF troops. However, this offensive was neither extensive nor systematic, so the declared objectives were not achieved (Home Office UK, 2004). In 2006, there were mainly attacks on military bases, but also an attack on the Chinese oil company Sinopec Limited in Obole, which killed more than 60 workers (Opalo, 2010). In response to these events, the Ethiopian army launched a very brutal offensive in early 2007, which was directed not only against ONLF but against all residents of the Somali Federated States. A trade blockade was launched, which, together with the drought that prevailed in Ogaden at the time, caused famine. In addition, there were mass arrests of people who were imprisoned for several years without trial. Another collective punishment was the burning of villages, where residents allegedly sympathized with ONLF or villages that allegedly supported or cooperated with ONLF. In 2010, government representatives met with representatives of ONLF in Frankfurt, Germany, where they signed a peace agreement to end the fighting. However, part of ONLF led by Muhammad Omar Osman disagreed with this agreement and created its own offshoot of ONLF called the Ogaden National Liberation Army (ONLA), which is still active in the area (Home Office UK, 2017). In 2013, ONLA relocated to the Somali capital of Mogadishu, where it plans and conducts all operations against the Ethiopian government. Clashes continue at low intensity, e.g. ONLA killed 23 Ethiopian soldiers in 2016 and more than 30 in 2017 (Harar24, 2017).

In order to discuss the spillover effect, there must be a temporal link between the conflict in Somalia and Ethiopia, as well as the involvement of some of the same actors. The conflict in Somalia began in 1991, after the collapse of the Barre regime and with varying intensity, this conflict has continued. The conflict was the most intensive in the first half of the 1990s and during the UIC's rise to power. During this first intensive period, spillover to neighboring Ethiopia began, specifically at the turn of 1993-1994. At the same time, it has been noted that the most intense fighting took place in Somalia in its central and southern parts, especially along the borders with Ethiopia and Kenya, which negatively affected the security situation in both countries (Menkhaus, 2007). Security threats have been spilled in border regions of Kenya and Ethiopia. This included arms and counterfeit trade, drug trafficking, increased terrorist activity, increased crime and an overall deterioration in the security situation compared to the national average (Gastrow, 2011). In the case of Ethiopia, the conflict itself was spilled over, which was also influenced by internal factors. It is obvious that there is a continuity of time in conflict's spillover.

The second factor discussed is the involvement of the same actors. According to the latest statistics, the Somali federal state occupies more than $95 \%$ of ethnic Somalis, in the 1990s this figure was a few percent lower, slightly above $90 \%$, but even in this 
period, the Somalis represented a majority group (Ethiopian Government, 2018). The vast majority of Somalia's people are ethnic Somalis, for whom ethnicity is not a key element, but clan membership is crucial. Major clans in Somalia include Darod, Dir, Hawiye, Isaaq, and Rahanweyn (Pham, 2013). The clans are then divided into several dozen sub-clans. The area along the border with Ethiopia is inhabited primarily by the Darod clan (roughly 2/3), followed by the Rahanweyn clan. A very similar ethnic demography is also along the border with Somalia in Ethiopian territory. This territory consists only of the Somali federal state, where the vast majority of the population are Somalis from the Darod tribe, namely the sub-clans of Ogaden, Jidwaq, and Marehan (Lewis, 1999). During the beginning of the Somali Civil War, the territory of Somalia was divided among the factions, which were created on a clan basis. Members of the individual clans worked together across Somalia, Ethiopia, and Kenya. Ethiopia's people were involved in the Somali conflict in Somali territory. At the same time, the Somalis very often crossed the international border and used the territory of the Somali Federal State to recruit new members, gain financial support and an environment for illegal trade, which was one of the main sources of income (IRB, 1999). Therefore, cooperation across the states was clear.

In addition to this clan involvement, cooperation and interdependence of some organizations are also evident. Specifically, it is a cooperation between ONLF and AIAI (Al-Ittihad Al-Islam - an armed Islamic organization that was established in 1990 in Somalia). Since 1990, the AIAI has operated not only in Somalia but also in the Somali Federal State of Ethiopia. The AIAI supported ONLF activity there until 1997 and the organizations discussed their activity together. There was also a common trade and training. It is therefore evident that one of the most active Somali organizations of the beginning of the civil war in Somalia has also influenced the Ethiopian organization ONLF (Terdman, 2008).

\section{Spillover of Conflict from Ethiopia to Djibouti}

Djibouti gained independence in 1977 until then it was a French colony. From the very beginning, there have been disputes between the two main ethnic groups. The Issas seized power, formed a single-party government in the country - the People's Union for Development (RPP - Rassemblement Popuilare pour le Progres) and oppressed the second largest ethnic group, Afars. ${ }^{2}$ Afars' disagreement with the central government resulted in a civil war between 1991 and 1994. It was a low-intensity conflict, as the number of victims does not exceed 260 (according to the UCDP), some estimates are higher but do not exceed 1000 (UCDP, 2017).

2 The Issas are a sub-clan of the Somali Clan Dir, so if we speak of an ethnic group, the Issas should be labeled as Somalis, but the Issas label is used more often (Lewis, 1999, p. 191). 
The situation within Djibouti was very tense in the 1980s. The Afars were increasingly marginalized. They were not represented in the government and parliament and were disadvantaged also in other areas. Tensions increased and also neighboring states had a negative impact on the situation as well. In Somalia, Barre was deposed in 1991 and civil war began in the country. In Ethiopia, the Mengistu was deposed and the regime changed. The unfavorable conditions in the immediate vicinity of the state, together with the worsening economic situation and economic crisis, had an impact on the already tense situation in Djibouti. The catalyst for the outbreak of the conflict itself was the wave of arrests of the Afars during January-August 1991. The arrests were based on alleged anti-state actions and disruptive tendencies of arrested people (Kadamy, 1996). At that time, three Afar organizations formed the Front for the Restoration of Unity and Democracy (FRUD), which began a violent guerrilla struggle against the government in the Obock region in November 1991 (ARDHD, 2008). In the initial phase of the conflict, there were series of bloody fighting between the Djibouti army and FRUD, especially in the north of the country near Obock and Tadjour. FRUD's units were very successful and largely managed to occupy this area. Therefore, the central government continued to arrest all FRUD supporters in all parts of the country. During the first six months of the conflict, Djibouti soldiers were very brutal towards the civilian population, with several incidents in the north of the country, they were firing into an unarmed crowd of civilians. Since 1992, France has evidently become involved in the conflict. The French representatives were trying to facilitate peace talks between the rebels and the government and also deployed French troops to help government troops to stop FRUD (ApNews, 1992). The last major government offensive was launched in July 1993 to clean up the last cities in the north of the country, which was still under FRUD's control. Government troops actually managed to push most of the FRUD's troops out of the territory, but the destruction of FRUD's units did not occur. FRUD retreated to mountain areas while crossing the boundaries of Eritrea and Somalia, where it began to manage its activity (Leta, Zeray and Haile, 2015, p. 5). The peace agreement was signed in December 1994, among other things, the ruling party of the RPP committed to liberalize and democratize the country. However, this transformation cannot be considered as successful, and despite tolerated opposition, elections in the country are not free and democratic, and the RPP continues to control its position of power (Freedom House, 2018).

In this section, two factors are discussed, the timing of the conflict in Djibouti with the conflict in Ethiopia, as well as the involvement of consensus actors. The Ethiopian Civil War took place between 1974-1991 and the most intense fighting took place in the late 1980s in three Ethiopian regions in the north - Amharia, Afar, and Tigray. From these areas that the conflict subsequently spilled over to Djibouti. There was a civil war in Djibouti between 1991-1994. The time continuity of the conflict is therefore evident, it is interesting that the conflict spilled at the end of the Ethiopian War, which is justified by the fact that in the 1970s most of the clashes took place in the central part of the 
country and eastern Ethiopia, while in the 1980s fighting has moved to the aforementioned north of the country. The key was the porosity of the border and the occurrence of the same ethnic groups in a neighboring state. Crossing the Djibouti border occurred early in the 1980s, particularly the ALF (ALF - Afar Liberation Front) used the border area and territory of Djibouti as a base for the preparation of attacks and they also recruited new members from that territory (Yohannes, Hadgu and Ambaye, 2005, p. 35). ${ }^{3}$

Disputes between the Somalis of the Issas and Afars tribes not only took place in the territory of Djibouti but also negatively affected the Afar region in Ethiopia. These disputes date back to the 19th century. Both groups form a nomadic community, while the vast majority of them profess Islam. Very often there have been disputes over water and pastures to which the Afars have historically claimed. The situation in Ethiopia and Djibouti was different. In Ethiopia, Afars have a majority in a regional state, so Issas are oppressed and discriminated against. They migrated to Djibouti during the second half of the 20th century to find a safer place. By contrast, Afars is a minority in Djibouti, where they are disadvantaged compared to Issas (Ahmed, 2009). During the civil war in Ethiopia, there was an exchange of inhabitants between the two areas and ALF used this border area as its base. At the end of the civil war in Ethiopia, some soldiers from the former Derg regime withdrew from Ethiopia to Djibouti. They left there a large number of weapons and military equipment after the war. At the same time, some of the soldiers joined the newly formed FRUD and, in the early stages of the conflict, represented the main combat component of the FRUD alongside the Eritreans (Yasin, 2010). Some ALF members also participated in the conflict and supported FRUD financially, technically and personally (Vaughan, 2011). This was also because they were dissatisfied with the EPRDF's progress and developments in Ethiopia after 1991. The Central Ethiopian government was concerned about the success of the FRUD and weakening its own position in the country since the Afars are not only a minority in Djibouti but in Ethiopia and Eritrea. Therefore, they asked the French to intervene against FRUD. In addition, they arrested several members and supporters of FRUD in their territory (Mohammed, 1996). Finally, the EPRDF ended cooperation with the ALF and created a new puppet party representing the Afars's interests in the country, the Afar People's Democratic Organization (APDO). From these data, it is evident that some ALF and Derg militants who participated in the war in Ethiopia moved after the end of the war to Djibouti, where they joined the local militias.

3 The Afar Liberation Front (ALF) was established in 1975 in Ethiopia as an armed militia fighting the Derg in the Afar region. Their main goal was to enforce more rights for the Afar ethnic group, which was particularly disadvantaged under the regime of Haile Selassie. 


\section{Spillover Effect of Conflicts in South Africa}

After the end of the Cold War, two conflicts spilled over into neighboring states in South Africa. The first one is a civil war in Angola, which took place between 1975-2002. In the initial phase, the main players were three parties, the MPLA (People's Movement for the Liberation of Angola), the FNLA (National Liberation Front of Angola) and the UNITA (National Union for the Total Independence of Angola) (Fiala, 2005). These three groups concluded an agreement in 1975, which failed after only a few months, and since the beginning of Angola's independence (11 November 1975), there has been an armed struggle in the country. MPLA took advantage of controlling the capital of Luanda and proclaiming all other parties to be rebels (Dyčka, 2010). In early 1976, the MPLA launched an offensive with the help of Cuban troops to push UNITA and FNLA out of the country. In the case of the FNLA, this offensive was truly successful and FNLA leader Holden Roberto had to flee the country. In the case of UNITA, the organization was pushed to the south but not pushed out of the country (Ferreira, 2006). In the following years, neither of these two parties gained a significant advantage, UNITA controlled the south of the country, MPLA the north. In 1988, South Africa agreed to grant Namibia independence and to stop support UNITA in exchange for withdrawing Cuban troops from Angola. This stopped the support of the two largest international actors in this conflict, Cuba and South Africa. The conflict itself ended in April 2002 with an attack on Savimbi, who died during the attack. An overwhelming majority of UNITA members followed the Lusaka agreement signed in 1994 (Saunders, 2009). This war spread into Namibia, where the conflict took place during 1999.

The second case is conflict in Cabinda, which spilled over to the Republic of Congo. ${ }^{4}$ In Cabinda, Front of the Liberation Enclave Cabinda (FLEC) has been fighting MPLA since the 1970s. FLEC attacked MPLA's units, but the intensity of the conflict was very low compared to the intensity of the fighting between UNITA and MPLA. FLEC controlled territories in the densely forested inland areas of the province and sporadically attacked the army and state targets. In 1983 there were personnel disputes within the FLEC leadership and the organization was divided into two groups, FLEC-Renovada (FLEC-R) and FLEC-FAC (Cabinda Armed Forces) (HRW, 2004). At the end of the 1990s, the intensity of the fighting increased, some UNITA members withdrew to the area and mass population movements took place. In October 2002, following the end of the civil war in Angola and the ultimate defeat of UNITA, the Central Angolan government regrouped its attention to Cabinda and sent 30,000 troops to the area to finally defeat FLEC. In 2004, the two wings of FLEC were merged, and at the same time, a series of

4 Cabinda is an enclave in the north, which has officially been part of Angola since 1956, although it has a different history and is not geographically linked to Angola as it is separated by the DRC zone (Porto, 2003, p. 11). 
peace negotiations between FLEC and MPLA began. The United FLEC, together with representatives of the Catholic Church of Cabinda and members of the Cabinda Civic Movement Mpalabanda, subsequently created the Cabindian Dialogue Forum (FCD). It should represent the interests of Canadians in peace negotiations (OMCT, 2015). Subsequently, in 2006, a peace treaty was signed between MPLA and FCD representative António Bento Bembe, who reportedly signed the agreement under duress without the consent of the majority of the FCD member (Southern Africa Monitor, 2006). Since this year, the government officially declares the end of the Cabinda's war, but members of the FLEC-FAC formation have not agreed to sign the treaty and continue to run attacks against government and military targets. Over the past few years, they have attacked government units and kidnapped foreign workers. They also attacked the national football team of Togo in 2010 (Guardian, 2010).

\section{Spillover of Conflict from Angola to Namibia}

The conflict in Angola spilled into neighboring Namibia into the Caprivi region. The people in this area have different ethnicities than the rest of Namibia, and since the time of German colonization, they have longed for independence and the right to self-determination. After Namibia's independence in 1990, SWAPO (South-West African People's Organization) seized power. Part of the Caprivi local political party DTA (Democratic Turnhalle Alliance) was dissatisfied with the full domination of SWAPO, and in 1994 they formed an organization called the Caprivi Liberation Army (CLA), which from the very beginning established a violent solution of the problem. On the $2^{\text {nd }}$ of August 1999, the CLA launched an offensive on the city of Katima Mulilo, the capital of the Caprivi region. CLA's units attacked several buildings, an army base, a police station, and a state radio station. During the fighting, 14 people died and more than 3,000 people were moved to neighboring Botswana (IRIN, 1999). A state of emergency was declared in the province and the government began to arrest all alleged members of the CLA. In August and September 1999, there were several other armed clashes between the CLA and the NDF (National Defense Forces), the last one took place in September. Major CLA members, including Mishake Muyongo, fled to neighboring states, especially Botswana. Some of them got granted asylum in European countries. Since these events, no other armed clashes have occurred.

The civil war in Angola took place between 1975-2002. As it was written in previous sections of the work, MPLA, which was for most of the conflict the ruling party controlled the north of the country, UNITA controlled the south. The conflict itself was characterized by a very different intensity in the course of time, the most intense fighting took place in three periods of time. The first of these periods was at the beginning of the conflict between 1976-1977, the second involved the offensive at Cuito Cuanavale, which represents the years 1985-1988. The third period was the most intense (in terms of the number of casualties and armed clashes) and this took place between 1998-2000. 
The spillover to Namibia occurred in 1998 when the first armed clashes between the rebels and the government began in Namibia. Thus, as in most previous cases, the conflict spilled over at the stage of its greatest intensity. At the same time, there is also an apparent time sequence. The interesting thing about this case is that the civil war in Angola was very long and the conflict spilled over almost at its end. The explanation is logical, as over the years UNITA had international support and controlled a large part of the territory. The organization used the territory and got from the territory financial resources and physical support. Moreover, South Namibia was dominated by South African SADF (until the early 1990s). UNITA had no reason to expand beyond Angola. Everything just changed in the 1990s, when Namibia gained independence, there were dozens of deserted military camps in its territory, used in the past by SADF units. These old camps were a great opportunity for UNITA when the organization was pushed out of most of Angola's territory (1998-2000). For these reasons, the spillover occurred in the late 1990s.

The Namibian population has been involved in the war in Angola since its inception. The SADF's government units consisted mainly of the people of South Africa, but also of the Namibians. However, a large part of the Namibians was involved in the fighting on the MPLA's side, supported by the revolutionary Namibian SWAPO. Even today it is relatively common in Namibia to meet someone who participated in these battles and remembers these events well. This is confirmed by the fact that it was indeed a very high involvement of several thousand. However, after independence, SWAPO and SADF withdrew from Angolan's territory in the vast majority of cases. SWAPO began to concentrate on events in the new state, first elections, constitutional creation and consolidation of power. However, there were several personal conflicts in the party and some of its major leaders left the party in the late 1980s and early 1990s. The best known is Mishake Muyongo, who was until 1980 a vice president of SWAPO. All these people withdrew to the north of the country, where they formed their own political organization DTA. Part of the DTA subsequently formed the CLA. In the 1990s, UNITA lost control of much of its territory, diamond mines, and parts of its physical base, and it was forced to withdraw to Namibia and Botswana. In Caprivi, UNITA used the former camps of SADF, which also served to train CLA units. In the mid-1990s, UNITA provided CLA with ammunition and equipment (Prendergast, 1999). The reason was UNITA's hatred of SWAPO for its involvement in MPLA fighting. In 1998, the Namibian NDF army discovered a training camp in the Caprivi area called Mudumu Game Park, where several CLA and UNITA members were involved (IRIN, 1999). The link between CLA and UNITA is, therefore, more than obvious. Moreover, experts from the University of Pretoria and Cape Town agree on the cooperation between UNITA and CLA (Irishtimes, 1999). In addition, four CLA members confirmed this link during an interview in Botswana (IrinNews, 1999). In this case, the rule is that the common enemy, which was (for UNITA and CLA) the SWAPO party, makes friends from two opposing parties. 


\section{Spillover of Conflict from Angola (Cabinda) to the Republic of Congo}

The war in Angola and the war in the province of Cabinda spilled over into the Republic of Congo. There were two civil wars in the 90s. The first one took place between 19931994 , and in terms of scale and intensity, the war was much milder and not so intense compared to the second civil war that took place between 1997-1999. The first civil war took place because of the disputes that followed the 1992 elections. The country was divided into three areas based on the support of individual candidates, the key was the ethnic division. In addition, militias were formed in these areas, the so-called Zulu militias supported Pascal Lissouba, Ninja militias supported Bernard Kolelas and Cobra militias supported President Sassou Nguessa (Englebert \& Ron, 2004). Lissouba's supporters have created other militias, such as the Cocoyes militia or Mambas militias. Fighting began between the Zulu and Ninja militias in the capital Brazzaville in the second half of 1993. During these fights, 2,000 people died. Ninja militias did not participate too much in the fighting. The violence ended in 1994.

Over the next two years, there was a restless peace in the country, which was occasionally disrupted by brief episodes of violence. New elections were to be held in July 1997, but the Lissouba's and Sassou's supporters had been preparing for armed confrontation since March. In May 1997, Sassou decided to candidate in the northern city of Owando, where the former President and former Prime Minister of Lissouba, Jacques Yhombi-Opango, came from. His speech led to the outbreak of violence between local supporters of Sassou (mostly Mbochi) and supporters of Yhombi (mostly Kouyou). In addition, Lissouba discovered that Sassou was arming his militias, so he decided to send an army to Sassou's residence to arrest some of his collaborators who were reportedly involved in the violence in Owando. Everything ended in a bloody shootout that unleashed violence throughout the capital. Thus the second civil war in Congo began (Trapnell \& Pflepsen, 2005). At the beginning of the war, the militias of Kolelas and Sassou cooperated against the militias of Lissouba, and Sassou was also supported by France. Lissouba cooperated with UNITA and FLEC troops, who he allowed since 1992 to legally reside in Congo. Lissouba and UNITA rebels have been working together since the 1990s. In the second largest city of Pointe-Noire, they smuggled weapons to assist local fighters. Angola joined the war in October 1997, sending about 3,000 troops to help Sassou. This induced Kolelas's cooperation with Lissouba. On the one side, the Ninja militia and the Cocoyes fought, on the other, the Angolan army and the Cobra militia. Sassou, thanks to the help of Angola, quickly gained the upper hand and Lissouba and Kolelas fled into exile in 1998. In the second half of 1998, the fighting shifted to the south of the country, but since January 1999 the intensity of the fighting decreased, until the end of 1999 rebellion ended in an agreement that provided amnesty to all commanders of Ninja and Cocoyes militias (Atzili, 2007). Sassou Nguesso came back to power and he reigns in the country until nowadays. 
The conflict in Angola itself took place between 1975-2002, and in Cabinda, the conflict lasted four years later, until 2006 (it is the official end on the basis of signing the peace treaty and the government declaration). Two civil wars took place in the Republic of Congo, in 1993-1994 and in 1997-1999. In the Second Civil War, UNITA and FLEC troops were involved, but also Angolan soldiers from the MPLA-controlled state army. Their presence decided the outcome of the conflict. The timing of the spillover of the conflict is evident in this case. The conflict spilled over at a time when there was still war in Angola. This is a very special period in terms of intensity since there was still a ceasefire in Angola in 1997, but since the beginning of 1998, bloody fights started again and the intensity of the conflict was very high. The key thing is that during this period, UNITA was pushed out of $2 / 3$ of the country's territory, and that is why it largely occupied the territory of the Republic of Congo and the DRC. At this time, FLEC controlled very limited, mostly rural areas of Cabinda and, like UNITA, made extensive use of neighboring states. So it can be said that this is a period when the presence of UNITA and FLEC troops in Congolese territory was the highest. In terms of intensity, however, the conflict was not spilled in its most intense phase.

Since the beginning of the Second Civil War in Congo, the cooperation of various militias with UNITA and FLEC troops has been evident. There was very extensive cooperation between the Lissouba's militias, especially the Zulu and Cocoyes militias, with the Angolan groups. UNITA and FLEC troops have been fighting on Lissouba's side since early 1997 and were included in his militia. As a result, UNITA received air shipments of weapons from the town of Pointe Noire, which was completely under the control of Lissouba (Turner, 2002). FLEC troops, on the other hand, received primarily financial support, but between them and the Lissouba's militias was cooperation since 1992, which included mainly arms trade, but in some cases, joint training of units. Angolan President Dos Santos was very worried about how the Congo war could affect the outcome of the civil war in Angola. Angolan military units (FAA - Angolan Armed Forces) involved in the fighting on the side of the Cobra militia. The intervention itself took place on October 12, 1997, when 3000 FAA soldiers entered the country. As a result, Sassou gained a very quick advantage and subsequently won.

\section{Analysis of Spillover Effect}

In this part of the work, a qualitative comparative analysis is used to compare conditions in all neighboring states of countries where conflicts took place and subsequently spilled over and in the other neighboring countries where it did not happen. For a detailed comparison of the factors described in the methodological section, the truth table has been created. If a given factor occurred in a neighboring state, it is assigned a value of 1 , if not a value of 0 . At the same time, it should be noted that I work with data from the time, when the conflict spilled over, not the latest data. The form of truth table can be seen in Annex 1. A computer program (Tosmana) was used to evaluate the results. In 
the beginning, it is necessary to explain the crosses in the table. In the case of the civil war in Somalia, a different political ideology was not included in the analysis. This is because there was no central government in Somalia in the 1990s to control most of the country and maintain a certain ideology. The country was divided among various factions that had different ideas and motives. Therefore, the state ideology cannot be compared with the ideologies of neighboring states. It is evident, at first sight from the table that economic factors did not play any role in these cases and therefore we can say there is no link between economic factors and the occurrence of the spillover effect. Therefore, the natural resources dimension does not play a significant role in these cases as it was only present in the case of the Republic of Congo. According to Collier, dependence on the export of one commodity increases the chance of conflict, but in practice of spillover effect, it does not apply. At the same time, it is obvious that there is no single explanation to clarify all the cases. Therefore, it is not possible to talk about causality and generalize the conclusions. There is only a coherence between the combination of factors and the occurrence of a spillover effect. To be able to talk about causality we would have to work with a greater number of cases. However, it is also clear from this analysis that some factors are more important than others.

Annex 1: Truth Table of Spillover in East and South Africa

\begin{tabular}{|c|c|c|c|c|c|c|c|c|c|c|c|c|c|c|c|c|c|c|c|c|c|}
\hline Case ID & $\begin{array}{l}\text { ல } \\
\text { கு }\end{array}$ & 응 & $\begin{array}{l}0 \\
\dot{O} \\
\text { க }\end{array}$ & $\begin{array}{l}\text { O } \\
\text { O̊ } \\
\text { க }\end{array}$ & $\begin{array}{l}0 \\
\stackrel{\circ}{0}\end{array}$ & ড্ & $\frac{\pi}{0}$ & 응 & $\frac{0}{0}$ & 흥 & $\stackrel{0}{\circ}$ & 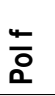 & 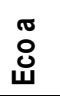 & 응 & $\begin{array}{l}0 \\
\text { ن }\end{array}$ & $\begin{array}{l}\pi \\
\stackrel{0}{ }\end{array}$ & @̊ & $\begin{array}{l}0 \\
\text { O } \\
\text { 心 }\end{array}$ & $\begin{array}{l}\text { ర } \\
\text { \& } \\
\text { ப் }\end{array}$ & 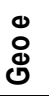 & Spillover \\
\hline Ethiopia & 1 & 1 & 0 & 1 & 1 & 1 & $x$ & 1 & 0 & 1 & 1 & 0 & 0 & 0 & 0 & 1 & 1 & 1 & 1 & 1 & 1 \\
\hline Kenya & 0 & 0 & 0 & 0 & 0 & 1 & $x$ & 1 & 0 & 1 & 0 & 0 & 0 & 0 & 0 & 0 & 0 & 1 & 1 & 1 & 0 \\
\hline Djibouti & 1 & 1 & 0 & 0 & 1 & 0 & $x$ & 0 & 1 & 1 & 1 & 1 & 0 & 0 & 1 & 0 & 0 & 0 & 0 & 0 & 0 \\
\hline Djibouti 2 & 1 & 1 & 0 & 1 & 1 & 1 & 1 & 0 & 1 & 1 & 1 & 1 & 0 & 0 & 1 & 0 & 0 & 0 & 0 & 0 & 1 \\
\hline Kenya & 0 & 1 & 0 & 0 & 0 & 0 & 1 & 1 & 0 & 1 & 0 & 0 & 0 & 0 & 0 & 0 & 0 & 1 & 1 & 1 & 0 \\
\hline Somalia & 1 & 1 & 0 & 1 & 1 & 0 & 0 & 1 & 1 & 1 & 1 & 0 & 0 & 0 & 1 & 1 & 1 & 0 & 0 & 0 & 0 \\
\hline Sudan & 0 & 1 & 0 & 0 & 0 & 0 & 1 & 1 & 1 & 1 & 1 & 0 & 1 & 1 & 0 & 0 & 1 & 1 & 1 & 1 & 0 \\
\hline Congo & 0 & 1 & 0 & 0 & 0 & 0 & 0 & 0 & 1 & 1 & 1 & 1 & 1 & 1 & 0 & 0 & 0 & 0 & 0 & 0 & 1 \\
\hline DRC & 0 & 1 & 0 & 0 & 1 & 1 & 0 & 1 & 1 & 1 & 1 & 0 & 1 & 0 & 1 & 1 & 1 & 1 & 1 & 1 & 0 \\
\hline Namibia & 1 & 1 & 0 & 0 & 0 & 0 & 0 & 0 & 1 & 1 & 1 & 1 & 0 & 0 & 0 & 1 & 0 & 0 & 1 & 1 & 1 \\
\hline Zambia & 0 & 1 & 0 & 0 & 0 & 0 & 0 & 0 & 1 & 0 & 0 & 1 & 0 & 0 & 1 & 1 & 0 & 0 & 1 & 1 & 0 \\
\hline
\end{tabular}

Source: Author

Overall, there are twelve combinations of factors whose presence in a neighboring state increases the likelihood of conflict's spillover. The political-security factors that have the most frequent representation seem to be crucial. Among these factors, the most represented factors are different political ideology, political instability, the existence of armed active militias and having a small army. Besides political-security factors, social and geographical are important as well. The most frequented social factor is a high 
occurrence of the same ethnicity in a neighboring state and the most frequented geographical factors are uneven ethnic demography and having a porous and long border. These are a combination of factors that increase the likelihood of spillover conflict and can even lead to spillover itself:

1. Political instability + existence of armed active militias + small army

2. Political instability + different ideology + small army

3. High occurrence of the same ethnicity + high crime rate + small army + porous and long border

4. Existence of armed active militias + small army + uneven ethnic demography

5. High crime rate + small army + uneven ethnic demography

6. Existence of armed active militias + small army + porous and long border

7. High occurrence of the same ethnicity + different ideology + small army

8. High occurrence of the same ethnicity + small army + porous and long border

9. Porous and long border + uneven population demography + uneven ethnic demography

10. Existence of armed active militias + porous and long border + uneven ethnic demography

11. High occurrence of the same ethnicity + porous and long border + uneven ethnic demography

12. High occurrence of the same ethnicity + high occurrence of the same religion + high influx of refugees

As you can see it at the combinations of factors, there are scenarios created just from political-security factors, but also scenarios that contain just social or geographical factors. It is therefore not possible to say which category is the most important and it is clear that all three categories (political-security, social and geographical) are important during conflict spillovers. On the other hand, economic factors are marginal compared to other factors. If we apply this analysis to theories about the description of the spillover effect and the causes of conflicts, we can say that the most accurate theories are the theories that Silver and Verdier created. However, even these theories do not fully cover our conclusions, and it is clear that spillover is a much more complex phenomenon, which must be explained by a combination of several factors, moreover, as can be seen from the analysis, there are several typologies of spillover.

\section{Conclusion}

The spillover effect is a phenomenon that accompanies some conflicts. It is most often seen in Africa and that is why this article deals with the analysis of the spillover effect on cases from South and East Africa. In the past, very few surveys on spillover effect analysis with the use of real examples have been conducted. Therefore, understanding and analyzing this phenomenon is very important. 
In the theoretical part of this work, the conditions that distinguish the spillover effect from the outbreak of a new conflict were clearly defined. This includes time continuity, the involvement of some of the same actors and the cooperation of local and neighboring actors. At the same time, I also focused on describing and determining the moment when the conflict spilled over (in terms of the intensity) to the neighboring state. Whether the conflict spilled over when the conflict was most intense, at the time of the ceasefire or after the conflict ended. The analysis shows that in all cases the spillover time continuity has been met. In three cases the spillover effect occurred at a time when the conflict had the greatest intensity. This is confirmed by a spillover of the conflict from Somalia, from Ethiopia and also by spillover from Angola to Namibia. The case of the spillover of the conflict from Angola to the Republic of Congo is specific. There was still a ceasefire in Angola in 1997, but since the beginning of 1998, bloody fights have started again and the intensity of the conflict has been very high. The key thing is that during this period, UNITA was pushed out of $2 / 3$ of the country's territory, and that is why it largely occupied the territory of the Republic of Congo. In addition, other organizations, such as MPLA units, were not involved in the conflict until 1998. In all cases, there was a spillover, when the fighting took place near the border or when the troops were pushed beyond the border. In all cases, the actors from the neighboring state were involved in conflicts and worked with local militias. They physically engaged in the fighting and fought on the side of their allies in all four cases. In some cases, financial and logistical support or bartering has also taken place, but physical involvement is crucial. From these cases, it is concluded that if there is intense fighting along the border, the chance of spillover is higher.

The second part of the work deals with the analysis of factors in neighboring states that increase the probability of spillover effect. In total, there are twelve combinations of factors that are key to spillover. The analysis shows that economic factors are irrelevant. On the other hand, we cannot say which of the remaining category of factors is the most important as there is always a scenario that increases the likelihood of spillovers and involves combinations of factors from only one category (either political-security or only social or geographic). However, the most prevalent factors can be identified. Among political- security factors it is: different political ideology, political instability, the existence of armed active militias and having a small army. The most frequented social factor is a high occurrence of the same ethnicity in a neighboring state and the most frequented geographical factors are uneven ethnic demography and having a porous and long border. All these factors are logical, because the long and porous borders make it easier to spillover the conflict, especially when fighting takes place along the border. If the era on a second side of the border is inhabited by the same ethnic group this area can serve as a good base for the militia. The same ethnicity increases the sense of belonging and this often leads to support for the militia. In cases, when the army is small it is not able to control its entire territory. Political instability leads to dissatisfac- 
tion among the local population and often creates space for new (sometimes violent) changes. In cases where there are already present armed active militias in the country, it is clear that something is not working in that state. This, in combination with other factors, can lead to the spillover of the conflict itself. It is therefore clear that these factors are not coincidental, and states in the immediate vicinity of the conflict should try to work on these issues to avoid the spillover of the conflict.

\section{References}

1. African Development Bank. (2008). The consequences of conflict. Abidjan: African Development Bank.

2. Ahmed, R. (2009). Undemocratic Threats are Hanging Over the Issa Tribe in Ethiopia. Paris: ARDHD.

3. ApNews. (1992, February 25). 250 French Troops Sent to Djibouti War Zone. Retrieved from https://apnews.com/d7b4b1b6a29a468f05130adad5ad7975.

4. ARDHD - Association pour le Respect des Droits de l'Homme à Djibouti. (2008, March 12). Pour la 12ème commémoration du massacre d'Arhiba.. Retrieved from http://www. ardhd.org/arhiba.asp.

5. Atzili, B. (2007). When Good Fences Make Bad Neighbors Fixed Borders, State Weakness, and International Conflict. International Security, 31, 139-173.

6. Bosker, M., \& de Ree, J. (2009). Localizing conflict spillovers: introducing regional heterogeneity in conflict studies. Groningen: University of Groningen.

7. Beneš, Vít, \& Drulák, Petr. (2016). Metodologie výzkumu politiky. Brno: Masaryk University.

8. Caramani, D. (2009). Introduction to the Comparative Method with Boolean Algebra. Los Angeles: Sage Publications.

9. Carmignani, F., \& Kler, P. (2013). Surrounded by wars: quantifying the role of spatial conflict spillovers. South East Queensland: Griffith University.

10. Collier, P., \& Hoeffler, A. (1999). Greed and Grievance in Civil War. NY: WorldBank.

11. Collier, P. (2007). Miliarda Nejchudších: Proč se některýmzemímnedaří a co s tím. Prague: Vyšehrad.

12. Dagne, T. (2010). Horn of Africa: Current Conditions and U.S Policy Committee on Africa and Global Health. Washington: FAC.

13. Dyčka, L. (2010). Aktéři surovinového konfliktu v Angole. Brno: Masaryk University.

14. Elbadawi, I., \& Sambanis, N. (2009). Why Are There So Many Civil Wars in Africa? Understanding and Preventing Violent Conflict. Washington: World Bank.

15. Enghoff, M., Hansen, B. et. al. (2010). Socio-economic and Environmental Impacts of Dadaab Refugee Camps on Host Communities. Kenya: Kenya Red Cross Society.

16. Englebert, P., \& Ron, J. (2004). Primary Commodities and War: Congo-Brazzaville's Ambivalent Resource Curse. Comparative Politics, 37, 61-81.

17. Ethiopian Government. (2018, January 25). Somali Regional State. Retrieved from http://www.ethiopia.gov.et/somali-regional-state. 
18. Ethiopian Parliament. (2017, Match 7). Ethiopian Parliament State Information. Retrieved from http://www.ethiopar.net/.

19. Ferreira, M. E. (2006). Angola Conflict and Development. The Economics of Peace and Security Journal, 1, 3-12.

20. Fiala, V. (2005). Vznik politických stran v zemích lusofonní Afriky. Politologická revue, 11, 91-138.

21. Fortna, V. P. (2008). Peacekeeping and the Peackept: Data on Peacekeeping in Civil Wars. New York: Columbia University Press.

22. Freedom House. (2018, January 25). Djibouti. Retrieved from https://freedomhouse. org/report/freedomworld/2011/djibouti?page=22\&year=2011\&country $=8026$.

23. Galula, D. (1964). Counterinsurgency Warfare. New York: Frederick A. Praeger.

24. Gastrow, P. (2011). Termites at Work: Transnational Organized Crime and State Erosion in Kenya. New York: International Peace Institute.

25. Gomez, M. P., Christensen, A., Araya, Y., \& Harild, N. (2010). The Impacts of Refugees on Neighboring Countries: A Development Challenge. Copenhagen: Social Development Department.

26. Guardian. Togo footballers were attacked by mistake, Angolan rebels say. (2010, June 5). Retrieved from https://www.theguardian.com/world/2010/jan/11/two-arrested-togofootball-attack.

27. Harar24. (2017, September 11). Ethiopian Soldiers killed in a heavy fighting between ONLF and Ethiopian Soldiers. Retrieved from http://harar24.com/?p=16329.

28. Home Office UK. (2004). Ethiopia Country Report. London: Home Office.

29. Home Office UK. (2017). Country Policy and Information Note: Ethiopia Opposition to the Government. London: Home Office.

30. Holsti, K.J. (1991). Armed Conflicts and International Order. Cambridge: Cambridge University.

31. Irin. (1999). Weekly Round-up 32 covering the period 7-13 August 1999. Johannesburg: IRIN.

32. IrinNews. (1999, September). UNITA training Caprivi rebels. Retrieved from http:// www.irinnews.org/report/7387/angola-namibia-unita-training-caprivi-rebels.

33. Irish Times. (1999, May 7). Namibia blames Savimbi for Caprivi secessionist rebellion. Retrieved from https://www.irishtimes.com/culture/namibia-blames-savimbi-forcaprivi-secessionist-rebellion-1.213335.

34. HRW. (2004). Angola Between War and Peace in Cabinda. Luanda: HRW.

35. IRB - Immigration and Refugee Board. (1999). Ethiopia: The Shekhash, a clan of Somali origin and their treatment in Ethiopia. Ottawa: IRB.

36. Kadamy, M. (1996). Djibouti Between War and Peace. Review of African Political Economy, 23, 511-521.

37. Kouba, K. (2008). Využití Millových metod ve srovnávací politologii: metodologické předpoklady a problémy. Olomouc: University of Palacky.

38. Leta, A., Zeray, Y., \& Haile, Y. (2015). The Politics of Dyadic Community: The Case of Djibouti. Ethiopia: Mekelle University. 
39. Lewis, I.M. (1999). A Pastoral Democracy: A Study of Pastoralism and Politics Among the Northern Somali of the Horn of Africa. Munster: International African Institute.

40. Menkhaus, K. (2007). The crisis in Somalia: Tragedy in five acts. Oxford: Oxford University Press.

41. Millett. R. L. (2002). Colombia's conflict - The spillover effects of wider war. Carlisle: US Army War College.

42. Mohammed, R. (1996). Djibouti: Between War and Peace. Connecticut: Praeger.

43. Ncube, M., \& Jones, B. (2013). Drivers and Dynamics of Fragility in Africa. Pretoria: AfDB.

44. OMCT. (2015). Angola - They Want to Keep Us Vulnerable. Luanda: OMCT.

45. Opalo, K. (2010). The Ogaden Region: A Fragile Path to Peace. Pretoria: Africa Backgrounder.

46. Patrick, S. (2006). Weak States and Global Threats: Assessing Evidence of "Spillovers“. London: Center for Global Development.

47. Pham, J. P. (2013). State Collapse, Insurgency and Counterinsurgency Lessons from Somalia. Carlisle PA: SSI.

48. Prendergast, J. (1999). Angola's Deadly War. Washington: USIP.

49. Porto, J. G. (2003). Cabinda, Notes on a soon-to-be-forgotten war. Pretoria: Institute for Security Studies.

50. Ragin, C. (2008). Redesigning Social Inquiry: Fuzzy Sets and Beyond. Chicago: University of Chicago Press.

51. Saunders, S. (2009). Angola from war to peace. Cape Town: University of Cape Town.

52. Silve, A., \& Verdier, T. (2018). Theory of regional conflict complexes. Québec: CRREP.

53. Smolík, J., \& Šmíd, T. (2010). Vybrané bezpečnostní hrozby a rizika 21. století. Brno: Mezinárodní politologický ústav.

54. Southern Africa Monitor. (2006). Peace Deal Lacks Credibility, 11, 1-3.

55. Terdman, M. (2008). Somalia at War - Between Radical Islam and Tribal Politics. Tel Aviv: Daniel Abraham Center for International and Regional Studies.

56. Terrill, A. (2008). Regional spillover effect of the Iraq war. Washington: U.S. Government.

57. Trapnell, T., \& Pflepsen, L. (2005). The Republic of Congo. New Jersey: Princeton University.

58. Turner, T. (2002). Angola's Role in the Congo War. In J.F. Clark (Ed.), The African Stakes of the Congo War. New York: Palgrave Macmillan.

59. UCDP -Uppsala Conflict Data Program (2017, January). Battle Related Deaths Dataset 1989-2016. Retrieved from http://ucdp.uu.se/downloads/.

60. Vaughan, S. (2011). Ethnicity and Power in Ethiopia. Edinburgh: University of Edinburgh.

61. Vestal, T. (1999). Ethiopia: A Post Cold War African State. Santa Barbara: Praeger Publishers.

62. Williams, Paul D. (2009). Into the Mogadishu Maelstrom: The African Union Mission in Somalia. International Peacekeeping, 16, 514-530. 
63. Whitaker, E.B. (2003). Refugees and the Spread of Conflict: Contrasting in Central Africa. North Carolina: University of North Carolina.

64. Yasin, M. (2010). Regional Dynamics of Inter-ethnic Conflicts in the Horn of Africa: An Analysis of the Afar-Somali Conflict in Ethiopia and Djibouti. Hamburg: The University of Hamburg.

65. Yohannes, G. M., Hadgu, K., \& Ambaye, Z. (2005). Addressing Pastoralist Conflicts in Ethiopia. London: Safeworld. 